\title{
Safflower seeds in the diet of feedlot lambs improved fat carcass, colour, and fatty acid profile of the meat
}

\author{
M.S. Ferreira ${ }^{1 \#}$, R.H.T.B. Goes ${ }^{2}$, A.C. Martinez ${ }^{1}$, J.R. Gandra ${ }^{2}$, A.R.M. Fernandes ${ }^{2}$, W.A. \\ Gonçales Júnior $^{1}$, C.A.L. Cardoso ${ }^{3}$, K.C.S. Brabes ${ }^{4} \&$ O.R. Machado Neto ${ }^{5}$ \\ ${ }^{1}$ Department of Veterinary Medicine, State University of Maringá (UEM), Umuarama, Paraná, Brazil \\ ${ }^{2}$ Departament of Animal Science, Federal University of Dourados (UFGD), Dourados, Mato Grosso do Sul, Brazil \\ ${ }^{3}$ Center Natural Resource Studies, State University Mato Grosso do Sul (UEMS), Dourados, Mato Grosso do Sul, Brazil \\ ${ }^{4}$ College of Engineering, Federal University of Dourados(UFGD), Dourados, Mato Grosso do Sul, Brazil \\ ${ }^{5}$ Departament of Animal Production, São Paulo State University (UNESP), Botucatu, São Paulo, Brazil
}

(Received 18 October 2018; Accepted 5 September 2019; First published online 18 November 2019)

Copyright resides with the authors in terms of the Creative Commons Attribution 4.0 South African Licence.
See: http://creativecommons.org/licenses/by/4.0/za
Condition of use: The user may copy, distribute, transmit and adapt the work, but must recognise the authors and the South African
Journal of Animal Science.

\begin{abstract}
The aim of this study was to evaluate intake, performance, carcass characteristics and meat quality of lambs fed finishing diets containing $0 \%, 7.5 \%$ and $15 \%$ safflower seeds (Carthamus tinctorius) as a replacement for corn and soybean meal. Thirty-six male lambs with mean bodyweight of $17.9 \pm 1.8 \mathrm{~kg}$ were randomly assigned to one of three treatments: C0: no safflower seeds, C7.5: 7.5\%safflower seeds in diet (DM basis), and C15: 15\% safflower seeds in diet (DM basis). The lambs were fed in pens of two and thus there were six replicates per treatment. Performance and carcass characteristics were not affected by including safflower seeds in their diet. Animals fed $7.5 \%$ safflower seeds had greater dry matter intake. There was a linear effect of increasing the redness $\left(a^{*}\right)$ of meat with the amount of safflower, where a mean of 15.77 was found for lambs that received the C15 diet. With increasing levels of safflower, the concentration of fatty acids C14:0, C17:0, and C22:1 increased. However, conjugated linoleic acid (CLA, $\mathrm{C} 18: 2)$ was reduced in lambs fed C15. A concentration of $0.461 \mathrm{~g} / 100 \mathrm{~g}$ meat was observed for animals that consumed C7.5. Thus, lambs fed a diet containing 7.5\% safflower had the greatest dry matter intake, carcass fat, and concentration of conjugated linoleic acid in their meat, and enhanced meat colour.
\end{abstract}

Keywords: conjugated linoleic acid, human health, lipid supplementation, oilseeds

"Corresponding author: mateusf.zoo@hotmail.com

\section{Introduction}

The use of oilseeds in animal feed increases the energy density of the diets and prevents metabolic disturbances that are caused by an excess of non-fibre carbohydrates, particularly rumen degradable starch. Supplementation of oilseeds for sheep may contribute to an increase in unsaturated fatty acids in the meat (Bolte et al., 2002), providing beneficial effects on human health, such as prevention of obesity, cardiovascular diseases and cancer, and modulation of the positive responses from the immune and inflammatory systems (Dilzer \& Park, 2012).

Safflower (Carthamus tinctorius) is an oilseed that contains $14 \%$ to $15 \%$ crude protein $/ \mathrm{kg}, 32.3-40 \%$ crude fibre $/ \mathrm{kg}$ and $27-32 \% \mathrm{fat} / \mathrm{kg}$, (Gecgel et al., 2007). It is rich in polyunsaturated fatty acids, with linoleic acid (C 18:2) representing 70-87\% of the total fatty acids (Coşge \& Gürbüz, 2007).

In ruminants, conjugated linoleic acid (CLA) can be formed by incomplete ruminal biohydrogenation or through an enzyme called stearoyl-CoA desaturase ( $\Delta$-9-desaturase), which is present in the intramuscular adipocyte, providing higher concentrations of CLA in the meat. Owing to its wide anticarcinogenic action and benefits to human health, the possibility of increasing the deposition of this fatty acid in red meat could be of great interest, but this effect happens only when sources of linoleic acid (C18:2) are provided as part of the diet (Mir et al., 2004).

The change in the fatty acid profile can become a strong factor of meat marketing. The reason is that the largest source of CLA for human consumption is found in products derived from ruminants. In recent 
years the consumer has become more conscious about the relationships between diet, health, and wellbeing, which causes an increase in demand for products with properties beneficial to health (De Smet \& Vossen, 2016).

Hence, the goal of the present study was to evaluate the performance, carcass characteristics, meat quality and fatty acid profile of the Longissimus muscle of lambs fed diets containing $0 \%, 7.5 \%$, and $15 \%$ of safflower seeds as a replacement for corn and soybean meal.

\section{Material and Methods}

The techniques and procedures used in the study were fully approved by the Ethics Committee on Animal Use, of the Federal University of Dourados (protocol number 021/2012). The trial was carried out between May and July 2016 in the Animal Reproduction sector, of the State University of Maringá, Campus of Umuarama, Paraná, Brazil. Animals were initially adapted to the facilities, management practices and diet. After that, a 62-day feeding trial was conducted.

Thirty-six six-month-old non-castrated lambs with an average bodyweight of $17.9 \pm 1.8 \mathrm{~kg}$ were weighed, dewormed, and housed with two animals per pen in concrete-floored stalls equipped with waterers and feed bunks. Animals were randomly assigned to one of three dietary treatments, in which safflower seeds were included in the proportions of $0 \%$ (C0) 7.5\% (C7.5), and 15\% (C15) of dry matter (DM). Thus, there were six pens per treatment. The safflower seed used in the diets had $10 \%$ moisture, $33 \%$ ether extract (EE), 16\% crude protein (CP), 44\% neutral detergent fibre (NDF), 32\% acid detergent fibre (ADF), and $2.8 \%$ ash. Their fatty acid composition is shown in Table 1. Experimental diets (Table 2) were formulated to be isoenergetic and to provide for an average daily gain (ADG) of $250 \mathrm{~g} /$ day, according to recommendations of NRC (NRC, 2007). Animals were fed twice daily (at $08 \mathrm{~h} 00$ and 16h00) with a concentrate to roughage ratio of 80: 20 and free access to water. Orts were removed daily when necessary, weighed and sampled to measure DM (method 930.15) according to AOAC (2005). Dry matter intake (DMI) was ad libitum with the orts anticipated to be $5 \%$ daily.

Table 1 Fatty acid profile of safflower seeds used to replace corn and soybean meal in the diets that were fed to lambs

\begin{tabular}{lcc}
\hline Fatty acids & Symbology & g per kg of oil \\
\hline Myristic & C14:0 & 1.1 \\
Pentadecanoic & $\mathrm{C} 15: 0$ & 0.5 \\
Palmitic & $\mathrm{C} 16: 0$ & 54.1 \\
Palmitoleic & $\mathrm{C} 16: 1$ & 0.8 \\
Margaric & $\mathrm{C} 17: 0$ & 0.4 \\
Cis-10- heptadecanoic & $\mathrm{C} 17: 1$ & 0.3 \\
Stearic & $\mathrm{C} 18: 0$ & 23.9 \\
Oleic & $\mathrm{C} 18: 1 \mathrm{n} 9$ & 129.3 \\
Linoleic & $\mathrm{C} 18: 2 \mathrm{n} 6$ & 764.8 \\
Linolenic & $\mathrm{C} 18: 3 \mathrm{n} 3$ & 2.2 \\
Arachidonic & $\mathrm{C} 20: 0$ & 4.6 \\
Eicosenoic & $\mathrm{C} 20: 1 \mathrm{n} 9$ & 2.8 \\
Behenic & $\mathrm{C} 22: 0$ & 9.0 \\
Erucic & $\mathrm{C} 22: 1$ & 3.0 \\
Lignoceric & $\mathrm{C} 24: 0$ & 1.7 \\
Nervonic & $\mathrm{C} 24: 1$ & 1.5 \\
Saturated fatty acids & - & 95.3 \\
Unsaturated fatty acids & - & 904.7 \\
Mono-unsaturated fatty acids & - & 137.7 \\
Poly-unsaturated fatty acids & - & 767.0 \\
\hline
\end{tabular}


Table 2 Proportion of feed ingredients and nutrient composition of experimental diets

\begin{tabular}{|c|c|c|c|}
\hline \multirow{2}{*}{ Ingredients, \% } & \multicolumn{3}{|c|}{ Treatments $^{1}$} \\
\hline & $\mathrm{CO}$ & C7.5 & C15 \\
\hline Ground corn & 59.0 & 54.4 & 49.8 \\
\hline Soybean meal & 16.0 & 13.1 & 10.2 \\
\hline Safflower seeds & 0.0 & 7.5 & 15.0 \\
\hline Tifton-85 hay & 20.0 & 20.0 & 20.0 \\
\hline Mineral supplement ${ }^{2}$ & 5.0 & 5.0 & 5.0 \\
\hline \multicolumn{4}{|l|}{ Nutrient levels (dry matter basis) } \\
\hline Crude protein, $\mathrm{g} / \mathrm{kg}$ & 144.6 & 139.8 & 134.9 \\
\hline Ether extract, g/kg & 14.0 & 37.5 & 61.0 \\
\hline Neutral detergent fibre, $\mathrm{g} / \mathrm{kg}$ & 229.6 & 254.5 & 279.5 \\
\hline NDF roughage, $\mathrm{g} / \mathrm{kg}$ & 154.0 & 154.0 & 154.0 \\
\hline Acid detergent fibre, $\mathrm{g} / \mathrm{kg}$ & 124.3 & 143.5 & 162.6 \\
\hline Ash, $\mathrm{g} / \mathrm{kg}$ & 13.9 & 16.7 & 18.6 \\
\hline Non-fibre carbohydrates, g/kg & 597.9 & 551.5 & 506.0 \\
\hline Metabolizable energy ${ }^{4}, \mathrm{MJ} / \mathrm{kg}$ & 11.38 & 11.43 & 11.51 \\
\hline
\end{tabular}

In analysing the chemical composition of the diets, safflower and hay, the samples were pre-dried for 72 hours in a forced ventilation oven at a temperature of $55^{\circ} \mathrm{C}$, and then milled in a Wiley mill with a 1-mm sieve to determine the DM (method 930.15), crude protein (CP) as nitrogen content multiplied by 6.25 (method 976.05), and ash (method 942.05) (AOAC, 2005). For NDF analysis, the samples were treated with alpha amylase at a stable temperature without sodium sulphite and corrected for ash (Mertens, 2002). Acid detergent fibre analysis was performed according to Van Soest et al., 1991.

The lambs were weighed individually at the beginning, during the experimental period at 14-day intervals, and at the end of the experiment to determine initial body weight (IBW), average daily gain (ADG) and final body weight (FBW), respectively. The average daily gain was obtained from the difference between weighing the lambs at the beginning and at the end of the experiment, and divided by the days of feedlot. After the 60 days of the experiment, the animals were scanned via ultrasound (Aloka ${ }^{\circledR}$ SSD-500, Aloka, Wallingford, CT, USA) using a $5 \mathrm{MHz}$ linear transducer. The animals were restrained, trichotomized in the dorsal space between the 12th and 13th thoracic vertebra, and then measured using the transducer positioned parallel to the dorsal median line. The measurements were LEA (loin eye area) and backfat thickness. Subsequently, the images were interpreted using Image ${ }^{\circledR}$ software that had been calibrated to convert pixel count at a known distance into millimetres. Backfat thickness was obtained from three measurements above the Longissimus dorsi muscle.

After 62 days of the experimental period, the animals were transported to the municipal slaughterhouse of the Experimental Farm of Iguatemi, Iguatemi, Paraná, Brazil, which belongs to the State University of Maringá. They were held without feed and water for 16 hours prior to slaughter. Animals were desensitized by stunning with electric discharge in the atlanto-occipital joint, followed by bleeding with an incision in the carotid artery and jugular vein, skinning and evisceration.

After slaughter, the carcasses were weighed to obtain the hot carcass weight (HCW) and subsequent calculation of the hot carcass dressing percentage (HCD). Cold carcass weight (CCW) was obtained 24 hours post mortem, while carcass external and internal length, rump length, leg length, rump circumference, and carcass and leg compactness were evaluated as described by Osório \& Osório (2003). Hot and cold carcass dressing percentage was calculated using HCW and CCW divided by final bodyweight (FBW) and then multiplying the result by 100 . Cooling loss percentage was calculated using hot CCW divided by HCW and multiplicated by 100 . 
To estimate the tissue composition of the carcasses, the shoulders of the left half carcasses were separated, weighed and dissected into subcutaneous fat, muscle tissue, intramuscular fat and bone. Subsequently, the tissue components (fat, muscle and bone) were weighed individually and the tissue percentage was calculated (Jardim et al., 2007).

The Longissimus dorsi muscles were separated from the left half carcass and transported to the Meat Technology Laboratory, UFGD, Dourados, Brazil. Excess fat was removed from the muscle with a scalpel for instrumental analysis and to determine approximate composition.

Three steaks of approximately $2.5 \mathrm{~cm}$ each were removed from the Longissimus dorsi and the colour of the meat was measured using a digital colorimeter (Minolta CR-400, Konica Minolta Sensing Americas Inc., Ramsey, NJ), using the CIE system $\left(L^{*}, a^{*}, b^{*}\right)$, in which $L^{*}$ represents the luminosity, $a^{*}$ indicates the intensity of red, and $\left(b^{*}\right)$ the intensity of the yellow (Houben et al., 2000). The colorimeter was calibrated before analysing the samples against white $\left(L^{*}=0\right)$ and black $\left(L^{*}=100\right)$ standards. Thirty minutes prior to the assessments, samples were removed from vacuum packages, and exposed to air to oxygenate the myoglobin (Abularach et al., 1998). The colour was measured at three points on each steak, and then averaged. The temperature and $\mathrm{pH}$ of the meat were measured at three points in each steak, using a portable digital peagameter with a penetration probe (Testo-205, Testo, Lenzkirch, BH, Germany).

The same three steaks were used to calculate the cooking loss $(\mathrm{CL})$. The samples were weighed and roasted in a pre-heated oven at $171{ }^{\circ} \mathrm{C}$. Samples were monitored every five minutes with a digital thermometer until the geometric centre of each steak reached $71^{\circ} \mathrm{C}$, when the steaks were removed from the oven (Wheeler et al., 1995). Total CL was calculated as the difference between the weights of the steak before and after cooking. Cooked steaks were then cooled for 24 hours at $4{ }^{\circ} \mathrm{C}$. Eight cores $(1.3 \mathrm{~cm}$ diameter), free of visible fat and connective tissue, were removed from each steak parallel to the long axis of the muscle fibres. Each core was sheared once through its centre, perpendicular to the fibre direction using a Warner-Bratzer shear machine (G-R Manufacturing Company, Manhattan, KS, USA). The texturometer was TA-XT2i (Texture Technologies, Hamilton, MA) and shear force values were recorded in $\mathrm{kg}$.

The water-holding capacity (WHC) was measured by compressing $2 \mathrm{~g}$ of Longissimus muscle with 10 $\mathrm{kg}$ pressure for 5 minutes. Water-holding capacity was calculated as the difference between the weight of the meat before and after the procedure, expressed as a percentage (Hamm, 1986).

To determine chemical composition, one steak from each animal was thawed at room temperature, cut in cubes, homogenized in a mixer and freeze-dried for 72 hours. Total lipids were extracted by the Soxhlet method (method 960.39) (AOAC, 1995); Crude protein was measured using the Kjeldahl method (method 976.05, $\mathrm{N} * 6.25$ ), moisture content (method 930.15) was determined by drying in an oven at $105{ }^{\circ} \mathrm{C}$ to constant weight, and ash (method 942.05) was obtained by incineration using a muffle furnace at $600{ }^{\circ} \mathrm{C}$ (AOAC, 2005).

For triglyceride transesterification, approximately $50 \mathrm{mg}$ lipid matter extracted from the sample was transferred to $15 \mathrm{~mL}$ Falcon tubes, and $2 \mathrm{~mL}$-heptan (Bligh \& Dyer, 1959) was added. The mixture was stirred until the grease material dissolved completely and $2 \mathrm{~mL} \mathrm{KOH} 2 \mathrm{~mol}$ per liter in methanol was added. The mixture was stirred for approximately 5 minutes. After phase separation, $1 \mathrm{~mL}$ of the upper layer (heptane and fatty acid methyl esters) was transferred to $1.5 \mathrm{~mL}$ Eppendorf vials (Hartman \& Lago, 1973). The vials were sealed hermetically, protected from light, and stored in a freezer at $-18{ }^{\circ} \mathrm{C}$ for further chromatographic analysis.

Fatty acid composition was determined by gas chromatography using a gas chromatograph with a flame ionization detector. For elution, a $100 \mathrm{~m} \times 0.25 \mathrm{~mm} \times 0.20 \mu \mathrm{m}$ fused silica capillary column was used. The oven temperature was programmed to start at $100^{\circ} \mathrm{C}$ and was maintained for 1 minute. After that, it was raised to $170{ }^{\circ} \mathrm{C}$ at a rate of $6.5^{\circ} \mathrm{C}$ per minute. Subsequently, the temperature was again raised from $170^{\circ} \mathrm{C}$ to $215^{\circ} \mathrm{C}$ at $2.75{ }^{\circ} \mathrm{C}$ per minute. This temperature was maintained for 30 minutes. Finally, the temperature was increased from 215 to $230^{\circ} \mathrm{C}$ at a rate of $40^{\circ} \mathrm{C}$ per minute. The injector and detector temperatures were $270^{\circ} \mathrm{C}$ and $280^{\circ} \mathrm{C}$, respectively. The $0.5 \mu \mathrm{L}$ samples were injected in split mode using nitrogen as a carrier gas at $1 \mathrm{~mL}$ per minute flow rate. Identification of the fatty acid methyl esters was performed by comparing the retention times of the sample compounds with the standard (Sigma) retention times eluted under the same conditions as the samples.

Indexes that were indicative of the healthfulness of the meat were calculated from the fatty acid profiles. Following Ulbricht \& Southgate (1991) the atherogenicity index (AI) was:

$$
A I=[(C 12: 0+(4 \times C 14: 0)+C 16: 0)] /\left(\sum A G M I+\sum \omega 6+\sum \omega 3\right), \text { and }
$$

the thrombogenicity index $(\mathrm{TI})$ was:

$$
\mathrm{TI}=(\mathrm{C} 14: 0+\mathrm{C} 16: 0+\mathrm{C} 18: 0) /\left[\left(0,5 \times \sum \mathrm{AGMI}\right)+\left(0.5 \times \sum \omega 6+\left(3 \times \sum \omega 3\right)+\left(\sum \omega 3 / \sum \omega 6\right)\right]\right.
$$



(2002):

The ratio of hypo- to hypercholesterolemic fatty acids $(\mathrm{h}: \mathrm{H})$ was calculated following Santos-Silva et al.

$$
h: H=(C 18: 1 c i s 9+C 18: 2 \omega 6+20: 4 \omega 6+C 18: 3 \omega 3+C 20: 5 \omega 3+C 22: 5 \omega 3+C 22: 6 \omega 3) /(C 14: 0+C 16: 0) .
$$

The data were tested for normality using PROC UNIVARIATE of SAS 9.3 (SAS, 2011) and then analysed by analysis of variance using PROC GLM (SAS, 2011). Pen was the experimental unit and treatments were considered a fixed effect. Thus, the model was:

$$
Y_{i j}=\mu+C_{i}+e_{i j}
$$

where: $Y_{i j}=$ an observation from the $\mathrm{j}^{\text {th }}$ pen

$\mu=$ overall mean

$C_{i}=$ the $\mathrm{i}^{\text {th }}$ safflower level $(0,7.5,15 \%$ DM basis $)$

$e_{i j}=$ experimental error

Orthogonal contrasts were used to determine the linear and quadratic effects of the level of safflower seeds in the diet. The results were calculated as LSMEANS and SEM. Significance was declared at $P<0.05$ and the trend was indicated by $P \leq 0.1$.

\section{Results and Discussion}

The levels of safflower grains in the experimental diets did not affect the performance of lambs (Table $3)$. However, the intake of dry matter in $\mathrm{kg} / \mathrm{day}$ and percentage of BW tended to have a quadratic effect $(P$ $=0.08$ ). That is, starting from $7.5 \%$ of safflower in the diet there was a reduction in DMI of lambs. This reduction can be explained by the higher EE consumption $(P<0.0001)$ of the $\mathrm{C} 15$ group animals compared with the C7.5 treatment. In ruminants, diets with EE content above 5\% reduce DMI (Palmquist \& Conrad, 1978). Similar performance results were found by Kott et al. (2010). However, no differences were found in the DMI lambs fed a diet containing $16.2 \%$ of safflower seed, when compared with lambs that were fed a diet without safflower. There was a linear decrease $(P<0.05)$ in the daily intake of non-fibre carbohydrates (NFC) when safflower was included in the experimental diets. Safflower replaced part of the corn and soybean bran in the experimental diets, and as a consequence, there was a reduction in the NFC amount of the diets, since the greater part of safflower nutrients are oil and fibre. However, there was a quadratic effect for the intake of CP, NDF, total digestible nutrients (TDN) and metabolizable energy (ME) $(P<0.1)$ (Table 4). This effect is explained by the higher DMI of the animals that consumed the C7.5 diet, providing greater intake of nutrients compared with the other treatments.

\begin{tabular}{|c|c|c|c|c|c|c|}
\hline \multirow{2}{*}{ Item $^{1}$} & \multicolumn{3}{|c|}{ Treatments $^{2}$} & \multirow{2}{*}{ SE } & \multicolumn{2}{|c|}{ Contrast $P$-value } \\
\hline & $\mathrm{CO}$ & $\mathrm{C} 7.5$ & C15 & & Linear & Quadratic \\
\hline Initial BW, kg & 16.70 & 16.82 & 16.68 & 2.232 & 0.990 & 0.910 \\
\hline Final BW, kg & 33.46 & 33.87 & 31.87 & 6.682 & 0.509 & 0.561 \\
\hline DMI, kg/day & 1.098 & 1,205 & 1.039 & 0.1487 & 0.502 & 0.088 \\
\hline DMI, \% BW & 3.30 & 3.55 & 3.26 & 0.003 & 0.840 & 0.077 \\
\hline ADG, kg/day & 0.270 & 0.275 & 0.245 & 0.0355 & 0.239 & 0.347 \\
\hline $\mathrm{G}: F, \mathrm{~kg} / \mathrm{kg}$ & 0.251 & 0.229 & 0.235 & 0.0309 & 0.389 & 0.399 \\
\hline
\end{tabular}

Table 3 Dry matter intake and performance of lambs fed diets with increasing levels of safflower seeds

\footnotetext{
${ }^{1}$ BW: bodyweight; DMI: dry matter intake, ADG: average daily gain, IBW: initial bodyweight, FBW: final bodyweight, G:F: gain to feed ratio feed

${ }^{2}$ C0: no safflower seeds; C7.5: diet with $7.5 \%$ safflower seeds DM basis; C15: diet with15\% safflower seeds on dry matter basis
} 
Table 4 Energy and nutrient intake of lambs fed diets with increasing levels of safflower seeds

\begin{tabular}{|c|c|c|c|c|c|c|}
\hline \multirow{2}{*}{ Item $^{1}$} & \multicolumn{3}{|c|}{ Treatments $^{2}$} & \multirow{2}{*}{ SE } & \multicolumn{2}{|c|}{ Contrast $P$-value } \\
\hline & $\mathrm{CO}$ & C7.5 & C15 & & Linear & Quadratic \\
\hline CP intake, kg/day & 0.179 & 0.189 & 0.157 & 0.0236 & 0,138 & 0,095 \\
\hline EE intake, kg/day & 0.018 & 0.050 & 0.071 & 0.0065 & $<0.0001^{*}$ & 0,074 \\
\hline NDF intake, kg/day & 0.284 & 0.345 & 0.326 & 0.0422 & 0.101 & 0.080 \\
\hline NFC intake kg/day & 0.739 & 0.746 & 0.591 & 0.0930 & $0.010^{*}$ & 0.101 \\
\hline TDN intake, kg/day & 0.910 & 1.003 & 0.871 & 0.1239 & 0.599 & 0.090 \\
\hline ME intake, MJ /day & 14.628 & 16.144 & 14.043 & 0.4761 & 0.616 & 0.089 \\
\hline
\end{tabular}

${ }^{1}$ CP: crude protein, EE: ether extract, NDF: neutral detergent fibre, TDN: total digestible nutrients, ME: metabolizable energy, NFC: non-fibre carbohydrates

${ }^{2}$ C0: no safflower seeds, C7.5: diet with $7.5 \%$ safflower seeds DM basis, C15: diet with15\% safflower seeds on dry matter basis

${ }^{\star} P<0.01$

Safflower grain levels had no effect on warm $(\mathrm{HCW})$ and cold $(\mathrm{CCW})$ carcass weights, warm $(\mathrm{HCY})$ and cold (CCY) carcass yields and on biometric variables, or on LEA and backfat thickness (Table 5).

Table 5 Carcass characteristics of lambs fed diets with increasing levels of safflower seeds

\begin{tabular}{|c|c|c|c|c|c|c|}
\hline \multirow{2}{*}{ Item $^{1}$} & \multicolumn{3}{|c|}{ Treatments $^{2}$} & \multirow{2}{*}{ SE } & \multicolumn{2}{|c|}{ Contrast $P$-value } \\
\hline & $\mathrm{CO}$ & C7.5 & C15 & & Linear & Quadratic \\
\hline Hot carcass weight, $\mathrm{kg}$ & 14.76 & 15.05 & 13.60 & 1.736 & 0.262 & 0.329 \\
\hline Hot carcass dressing, $\%$ & 44.18 & 44.35 & 42.97 & 2.491 & 0.415 & 0.540 \\
\hline Cold carcass weight, $\mathrm{kg}$ & 14.51 & 14.81 & 13.34 & 1.750 & 0.262 & 0.327 \\
\hline Cold carcass dressing, $\%$ & 43.42 & 43.64 & 42.10 & 2.298 & 0.334 & 0.454 \\
\hline Cooling loss, \% & 1.70 & 1.58 & 1.98 & 1.192 & 0.694 & 0.672 \\
\hline External length, $\mathrm{cm}$ & 57.00 & 56.58 & 57.16 & 3.225 & 0.929 & 0.760 \\
\hline Internal length, cm & 51.83 & 52.33 & 49.25 & 2.639 & 0.110 & 0.194 \\
\hline Rump length, cm & 24.91 & 24.83 & 24.33 & 2.219 & 0.655 & 0.853 \\
\hline Leg length, $\mathrm{cm}$ & 31.75 & 31.33 & 32.33 & 2.583 & 0.701 & 0.591 \\
\hline Rump circumference, cm & 59.50 & 59.50 & 57.75 & 2.826 & 0.300 & 0.545 \\
\hline $\mathrm{CCl}, \mathrm{kg} / \mathrm{cm}$ & 0.28 & 0.28 & 0.27 & 0.027 & 0.551 & 0.584 \\
\hline $\mathrm{LCl}, \mathrm{kg} / \mathrm{cm}$ & 0.79 & 0.80 & 0.76 & 0.108 & 0.674 & 0.668 \\
\hline LEA, $\mathrm{cm}^{2}$ & 13.70 & 13.49 & 11.88 & 2.184 & 0.168 & 0.534 \\
\hline Backfat thickness, mm & 2.50 & 2.78 & 2.32 & 0.581 & 0.630 & 0.222 \\
\hline
\end{tabular}

${ }^{1} \mathrm{LCl}$ : leg compactness index, LEA: loin eye area

${ }^{2}$ C0: no safflower seeds, C7.5: diet with $7.5 \%$ safflower seeds DM basis, C15: diet with15\% safflower seeds on dry matter basis

There was a linear decrease $(P<0.05)$ in the amount of muscle $(\mathrm{kg})$ in lambs that were fed increasing amounts of safflower (Table 6 ). This effect was a reflection of the reduction in CP levels when safflower was added to the diets (Table 2). According to Cabral et al. (2008), lambs produced in Brazilian systems with a bodyweight of $30 \mathrm{~kg}$ and ADG of $250 \mathrm{~g} /$ day require $168 \mathrm{~g} \mathrm{CP}$ daily. Lambs fed the C15 diet did not attain this level of CP intake, which may have impaired their deposition of muscle. The amount and percentage of fat from the shoulders also tended to have a quadratic effect $(P<0.1)$, with increasing levels of safflower grain 
being included in the diet. This effect can be explained by the greater intake of ME (Table 4) by the group that was fed the $\mathrm{C} 7.5$ diet.

Table 6 Weight and tissue percentage of shoulders of lambs fed diets with increasing levels of safflower seeds

\begin{tabular}{|c|c|c|c|c|c|c|}
\hline \multirow{2}{*}{ Item } & \multicolumn{3}{|c|}{ Treatments $^{1}$} & \multirow{2}{*}{ SE } & \multicolumn{2}{|c|}{ Contrast $P$-value } \\
\hline & $\mathrm{CO}$ & C7.5 & C15 & & Linear & Quadratic \\
\hline Shoulder, kg & 1.35 & 1.36 & 1.24 & 0.170 & 0.279 & 0.472 \\
\hline Muscle, $\mathrm{kg}$ & 0.89 & 0.86 & 0.79 & 0.081 & $0.044^{*}$ & 0.579 \\
\hline Muscle, \% & 66.33 & 63.86 & 63.94 & 3.029 & 0.192 & 0.412 \\
\hline Bone, $\mathrm{kg}$ & 0.28 & 0.26 & 0.28 & 0.092 & 0.975 & 0.620 \\
\hline Bone, \% & 20.80 & 18.36 & 22.57 & 5.807 & 0.605 & 0.269 \\
\hline Fat, kg & 0.18 & 0.24 & 0.17 & 0.069 & 0.869 & 0.093 \\
\hline Fat, \% & 12.85 & 17.77 & 13.47 & 4.794 & 0.826 & 0.074 \\
\hline
\end{tabular}

${ }^{1}$ C0: no safflower seeds, C7.5: diet with $7.5 \%$ safflower seeds DM basis, C15: diet with15\% safflower seeds on dry matter basis

${ }^{*} P<0.05$

The treatments had no effect on the pH of the meat. However, $\mathrm{a}^{*}$ increased linearly $(P<0.05)$ with the level of safflower seed in the diet (Table 7), with the greatest values for red index being found for meat from animals that were fed a diet containing $15 \%$ safflower seeds. Safflower has approximately $60 \mathrm{mg}$ tocopherol per $100 \mathrm{~g}$ seeds (Matthaus et al., 2015). In the current experiment, the animals fed C7.5 and C15 had intakes of 54.22 and $93.51 \mathrm{mg}$ of tocopherol per day, respectively. According to Sales \& Koukolová, (2011), the intake of $50 \mathrm{mg}$ to $100 \mathrm{mg}$ of tocopherol per day via diet generates a muscular accumulation of tocopherol of $3 \mu \mathrm{g} / \mathrm{g}$ to $4 \mu \mathrm{g} / \mathrm{g}$, which would be enough to reduce lipid oxidation. These authors also showed a direct relationship between muscle tocopherol concentration and red intensity. Tocopherol functions to neutralize the formation of free radicals and inhibit lipid oxidation (Bellés et al., 2019). Ragni et al. (2015) found no difference in the red index $\left(a^{*}\right)$ of the meat from kids fed safflower pie compared with a control group, which could be explained by the relatively low ingestion of tocopherol ( $37.2 \mathrm{mg} /$ day) compared with the present study. A more intense red colour of meat may be desirable to the consumer. According to Calnan et al. (2014), the colour of sheep meat is crucial to attracting the customer and contributes heavily to the value of the product. No differences were detected in shear force, cooking losses and water-holding capacity in the meat of lambs that were fed safflower seeds diets (Table 7).

The increased level of safflower seeds in the diets did not influence the chemical composition of the Longissimus muscle of lambs (Table 8). The chemical characteristics of the meat aim to carry updated and reliable nutritional information of the final product, showing what consumers will consume (Van Cleef et al., 2017). Therefore, changes in the nutritional values of meat may be undesirable to the consumer. Other studies evaluating the quality of the meat of small ruminants fed safflower diets showed no effect of the oilseed on the chemical composition of the meat (Dry Matter, CP, Ether Extract, and Mineral content) (Bolte et al., 2002; Ragni et al., 2015). 
Table 7 Qualitative characteristic of Longissimus muscle from lambs fed diets with increasing levels of safflower seeds

\begin{tabular}{|c|c|c|c|c|c|c|}
\hline \multirow{2}{*}{ Item $^{1}$} & \multicolumn{3}{|c|}{ Treatments $^{2}$} & \multirow{2}{*}{ SEM } & \multicolumn{2}{|c|}{ Contrast $P$-value } \\
\hline & $\mathrm{CO}$ & C7.5 & C15 & & Linear & Quadratic \\
\hline L & 35.97 & 33.10 & 35.58 & 4.965 & 0.895 & 0.297 \\
\hline$A$ & 13.72 & 14.45 & 15.77 & 1.256 & $0.012^{*}$ & 0.642 \\
\hline B & 4.83 & 4.90 & 6.44 & 2.003 & 0.184 & 0.470 \\
\hline WBSF, kgf & 2.78 & 2.69 & 2.45 & 0.962 & 0.555 & 0.875 \\
\hline $\mathrm{Ph}$ & 5.75 & 5.79 & 5.73 & 0.301 & 0.924 & 0.720 \\
\hline Temperature, ${ }^{\circ} \mathrm{C}$ & 15.93 & 15.66 & 15.91 & 1.096 & 0.979 & 0.644 \\
\hline WHC, $\%$ & 0.30 & 0.28 & 0.25 & 0.057 & 0.131 & 0.931 \\
\hline CL, \% & 37.66 & 36.98 & 33.71 & 6.437 & 0.304 & 0.693 \\
\hline
\end{tabular}

\footnotetext{
${ }^{1}$ L: luminosity index of meat, a: red index of meat, b: yellow index of meat, WBSF: Warner-Bratzler shear force, WHC: water-holding capacity, CL: cooking loss

${ }^{2}$ C0: no safflower seeds, C7.5: diet with $7.5 \%$ safflower seeds on dry matter basis, C15: diet with15\% safflower seeds on dry matter basis

${ }^{*} P<0.05$
}

Table 8 Qualitative characteristic of Longissimus muscle from lambs fed diets with increasing levels of safflower seeds

\begin{tabular}{|c|c|c|c|c|c|c|}
\hline \multirow{2}{*}{ Item } & \multicolumn{3}{|c|}{ Treatments $^{1}$} & \multirow{2}{*}{ SEM } & \multicolumn{2}{|c|}{ Contrast $P$-value } \\
\hline & $\mathrm{CO}$ & C7.5 & C15 & & Linear & Quadratic \\
\hline Moisture, \% & 69.14 & 69.83 & 69.26 & 2.591 & 0.171 & 0.408 \\
\hline Fat, \% & 4.87 & 4.83 & 5.38 & 1.111 & 0.432 & 0.602 \\
\hline Ash, \% & 0.24 & 0.25 & 0.23 & 0.059 & 0.713 & 0.670 \\
\hline Protein, \% & 23.01 & 23.02 & 24.41 & 2.081 & 0.254 & 0.508 \\
\hline
\end{tabular}

\footnotetext{
${ }^{1}$ C0: no safflower seeds, C7.5: diet with $7.5 \%$ safflower seeds DM basis, C15: diet with15\% safflower seeds on dry matter basis
}

Supplementation with safflower seeds promoted changes in the fatty acid profile of the longissimus muscle in lambs (Table 9). With increasing levels of safflower in the experimental diets, linear increases $(P$ $<0.05)$ were observed in the concentration of myristic (C14:0), heptadecanoic (C17:0), and erucic (C22:1) fatty acids. The increase in the concentration of $\mathrm{C} 14: 0$ can be explained by the greater abundance of this fatty acid in the oil of the safflower grains (Table 1) compared with corn ( $0.6 \mathrm{~g} / \mathrm{kg}$ of oil) and soybean bran ( $0.5 \mathrm{~g} / \mathrm{kg}$ of oil) (Kostik et al., 2013). When C14:0 is provided in the ruminant diet, higher amounts of it can be found in the fat of the final products (meat and milk) (Odongo et al., 2007). However, the amount of myristic acid that is ingested in the diets of human beings is small, so this saturated fatty acid contributes little to the risk of cardiovascular disease (Nettleton et al., 2017). Odd chain fatty acids, such as heptadecanoic acid (C17:0) originate from synthesis of microbial protein in the rumen, which can be impaired by a decrease in ruminal $\mathrm{pH}$. Relative to the present results, the reduced intake of CNF by lambs that were supplemented with safflower (Table 4) may have caused a ruminal pH stability owing to the lower synthesis of SCFAs from the fermentation of NFC, increasing the synthesis of microbial protein and as a consequence the amount of $\mathrm{C} 17: 0$ in the meat. This effect may be desirable for consumers as higher levels of C17:0 in meat are associated with lower rates of Type 2 diabetes and reduced risks of cardiovascular and coronary disease (Calder, 2015; Jenkins et al., 2015) 
Table 9 Fatty acid profile ( $\mathrm{g} / 100 \mathrm{~g}$ of meat) of Longissimus muscle from lambs fed diets with increasing levels of safflower seeds

\begin{tabular}{|c|c|c|c|c|c|c|}
\hline \multirow{2}{*}{ Item $^{1}$} & \multicolumn{3}{|c|}{ Treatments $^{2}$} & \multirow{2}{*}{ SEM } & \multicolumn{2}{|c|}{ Contrast $P$-value } \\
\hline & $\mathrm{CO}$ & C7.5 & C15 & & Linear & Quadratic \\
\hline C10:0 & 0.108 & 0.108 & 0.106 & 0.0068 & 0.678 & 0.810 \\
\hline C12:0 & 0.116 & 0.121 & 0.125 & 0.0088 & 0.122 & 0.852 \\
\hline C14:0 & 2.653 & 2.708 & 2.808 & 0.1148 & $0.033^{*}$ & 0.700 \\
\hline C14:1c9 & 0.105 & 0.108 & 0.106 & 0.0061 & 0.645 & 0.428 \\
\hline C15:0 & 0.213 & 0.211 & 0.223 & 0.0233 & 0.468 & 0.575 \\
\hline C16:0 & 24.243 & 24.243 & 24.301 & 0.4783 & 0.835 & 0.904 \\
\hline C16:1c9 & 1.570 & 1.600 & 1.585 & 0.0319 & 0.429 & 0.179 \\
\hline C17:0 & 1.435 & 1.471 & 1.505 & 0.0536 & $0.039^{*}$ & 0.951 \\
\hline C18:0 & 18.680 & 18.398 & 18.391 & 0.4239 & 0.257 & 0.526 \\
\hline C18:1 cis9 & 43.733 & 43.715 & 43.535 & 0.4753 & 0.481 & 0.738 \\
\hline C18:2n6 & 3.530 & 3.573 & 3.526 & 0.0898 & 0.949 & 0.331 \\
\hline C18:3n3 & 0.168 & 0.176 & 0.176 & 0.0088 & 0.120 & 0.356 \\
\hline C18:2 CLA & 0.458 & 0.461 & 0.416 & 0.0337 & $0.047^{\star}$ & 0.168 \\
\hline C20:0 & 0.108 & 0.110 & 0.110 & 0.0057 & 0.618 & 0.773 \\
\hline C20:1 & 0.103 & 0.103 & 0.101 & 0.0048 & 0.559 & 0.734 \\
\hline C20:2 & 0.105 & 0.106 & 0.101 & 0.0049 & 0.261 & 0.197 \\
\hline C20:3n6 & 0.105 & 0.101 & 0.105 & 0.0051 & 1.000 & 0.207 \\
\hline C20:3n3 & 1.498 & 1.536 & 1.476 & 0.0971 & 0.704 & 0.327 \\
\hline C20:4n6 & 0.195 & 0.190 & 0.195 & 0.0077 & 1.000 & 0.216 \\
\hline C20:5n3 & 0.101 & 0.105 & 0.105 & 0.0062 & 0.369 & 0.600 \\
\hline $\mathrm{C} 22: 1$ & 0.768 & 0.848 & 0.996 & 0.1346 & $0.010^{*}$ & 0.619 \\
\hline
\end{tabular}

${ }^{1}$ Capric C10:0; Lauric C12:0; Miristic C14:0; Myristoleic C14:1; Pentadecylic C15:0; Palmitic C16:0; Palmitovaccenic C16:1; Margaric C17:0; Stearic C18:0; Oleic C18:1; Linoleic C18:2; Rumenic C18:2; Linolenic C18:3; Arachidic C20:0; Eicosaenoic C20:1; Dihomo-linoleic C20:2; Dihomo-y-linolenic (20:3); Dihomo-a-linolenic (20:3); Arachidonic C20:4; Eicosapentaenoic (20:5); Erucic (22:1)

${ }^{2}$ C0: no safflower seeds, C7.5: diet with $7.5 \%$ safflower seeds DM basis, C15: diet with15\% safflower seeds on dry matter basis

${ }^{\star} P<0,05$

A linear decrease with increasing amounts of dietary safflower was observed $(P<0.05)$ for CLA concentrations. However, the animals that received the $\mathrm{C} 7.5$ treatment presented greatest concentrations of muscular CLA (0.461 g/100g). This effect may be associated with higher NDF intake of lambs (Table 4), favouring ruminal biohydrogenation of linoleic acid (C 18:2). Vaccenic acid (trans-11 18:1) and CLA in the meat and milk are examples of incomplete ruminal biohydrogenation of linoleic acid (C18:2) (Loor et al., 2004). However, for most CLA isomers that have been identified in ruminant products, Kott et al., 2003 observed higher values of CLA in the muscle of lambs that received safflower grains $(0.85 \mathrm{~g} / 100 \mathrm{~g}$ meat) in their diet compared with the control group $(0.40 \mathrm{~g} / 100 \mathrm{~g}$ meat). There was a linear increase in erucic fatty acid concentration (C 22:1, n-9) with the increase in the amount of dietary safflower, which was due to the presence of this fatty acid in safflower seed (Table 1 ).

The total concentrations of saturated, unsaturated and polyunsaturated fatty acid, and the fatty acid ratio were not influenced $(P>0.05)$ by the inclusion of safflower in the experimental diets (Table 10). There was no significant effect $(P>0.05)$ on the ratio between hypo- and hypercholesterolemic fatty acids $(\mathrm{h}: \mathrm{H})$, or for the atherogenicity index (Al), the thrombogenicity index $(\mathrm{TI})$, and the n6:n3 ratio (Table 10). 
Table 10 Saturated fatty acid, unsaturated fatty acid, monounsaturated fatty acid, polyunsaturated fatty acid and unsaturated-to-saturated ratio of Longissimus muscle from lambs fed diets with increasing levels of safflower seeds

\begin{tabular}{lcccccc}
\hline \multirow{2}{*}{ Item $^{1}$} & \multicolumn{3}{c}{ Treatments $^{2}$} & & \multicolumn{2}{c}{ Contrast $P$-value } \\
\cline { 2 - 3 } & C0 & C7.5 & C15 & & Linear & Quadratic \\
\hline SFA, g/100 g meat & 47.558 & 47.373 & 47.572 & 0.5341 & 0.966 & 0.483 \\
UFA, g/100 g meat & 52.442 & 52.627 & 52.428 & 0.5301 & 0.996 & 0.483 \\
MUFA, g/100 g meat & 46.280 & 46.375 & 46.325 & 0.5303 & 0.885 & 0.788 \\
PUFA, g/100 g meat & 6.161 & 6.251 & 6.103 & 0.1606 & 0.538 & 0.158 \\
UFA:SFA & 1.103 & 1.111 & 1.102 & 0.2331 & 0.964 & 0.475 \\
n6:n3 & 23.184 & 22.401 & 22.048 & 1.4467 & 0.193 & 0.770 \\
Al & 0.676 & 0.678 & 0.689 & 0.0203 & 0.291 & 0.669 \\
TI & 1.851 & 1.836 & 1.846 & 0.0429 & 0.848 & 0.566 \\
h:H & 1.776 & 1.773 & 1.754 & 0.0500 & 0.468 & 0.746
\end{tabular}

${ }^{1}$ SFA: saturated fatty acid, UFA: unsaturated fatty acid, MUFA: monounsaturated fatty acid, PUFA: polyunsaturated fatty acid, Al: atherogenicity index, $\mathrm{Tl}$ : thrombogenicity index, $\mathrm{h}: \mathrm{H}$ : ratio of hypocholesterolemic to hypercholesterolemic

${ }^{2}$ C0: no safflower seeds, C7.5: diet with 7.5\% safflower seeds DM basis, C15: diet with15\% safflower seeds on dry matter basis

\section{Conclusion}

Safflower seeds may replace corn and soybean meal in the diet of lambs and improve the colour and fatty acid profile of the meat without damaging performance and carcass traits. Lambs fed a diet containing $7.5 \%$ safflower seeds had the greatest DMI, fat in the carcass, and fatty acids that are beneficial to human health Therefore, feeding lambs a diet containing $7.5 \%$ safflower seeds could be recommended.

\section{Acknowledgements}

The Coordination for the Improvement of Higher Level Personnel (CAPES); Federal University of DouradosUFGD and State University of Maringá-UEM, Foundation to Support the Development of Education, Science and Technology of the State of Mato Grosso do Sul (FUNDECT) and National Council of Scientific and Technological Development (CNPq) are acknowledged for funding part of this study. L.C.F. de Souza donated the safflower used in the research.

\section{Authors' Contributions}

MSF participated in designing the study, collected the data, performed laboratory analysis, interpreted the statistical analysis and wrote the manuscript. WAGJ and ACM collected the data. RHTBG designed the study and revised the manuscript. JRG performed statistical analysis. CALC and KCSB performed laboratory analysis. ORMN interpreted the data and revised the manuscript. ARMF performed laboratory analysis and revised the manuscript. All authors approved the final manuscript.

\section{Conflict of Interest Declaration}

No potential conflict of interest was reported by authors.

\section{References}

Abularach, M.L., Rocha, C.E. \& Felicio, P.E., 1998. Características de qualidade do contra-filé (m. L. dorsi) de 42 touros jovens da raça Nelore. Food Sci. Tech. 18, 205-210 https://doi.org/10.1590/S0101-20611998000200012

AOAC International, 1995. Official methods of analysis. 16th ed. Association of Official Analytical Chemists, Inc. Washington, DC, USA.

AOAC International, 2005. Official methods of analysis. 18th ed. Association of Official Analytical Chemists, Inc. Washington, DC, USA

Bellés, M., Del Marc Campo, M., Roncalés, P. \& Beltrán, J.A., 2019. Supranutritional doses of vitamin E to improve lamb meat quality. Meat Sci. 149, 14-23. https://doi.org/10.1016/j.meatsci.2018.11.002

Bligh E. G. \& Dyer W. J., 1959. A rapid method of total lipid extraction and purification. Can. J. Biochem. Physiol. 37: 911-917.

Bolte, M. R., Hess, B. W., Means, W. J., Moss, G. E. \& Rule, D. C., 2002. Feeding lambs high-oleate or high-linoleate safflower seeds differentially influences carcass fatty acid composition. J. Anim. Sci. 80, 609-616. https://doi.org/10.2527/2002.803609x 
Cabral, L. S., Neves, E. M. O., Zervoudakis, A. L. \& Oliveira, I. S., 2008. Estimativas dos requisitos nutricionais de ovinos em condições brasileiras. Nutrients. Rev. Bras. saúde e produção Anim. 9, $529-542$. https://doi.org/10.1016/j.foodchem.2007.06.021

Calder, P. C., 2015. Functional roles of fatty acids and their effects on human health. J. Parenter. Enter. Nutr. 39, 18S32S. https://doi.org/10.1177/0148607115595980

Calnan, H. B., Jacob, R. H., Pethick, D. W. \& Gardner, G. E., 2014. Factors affecting the colour of lamb meat from the longissimus muscle during display: The influence of muscle weight and muscle oxidative capacity. Meat Sci. 96, 1049-1057. https://doi.org/10.1016/j.meatsci.2013.08.032

Chin, S. F., Liu, W., Storkson, J. M., Ha, Y. L. \& Pariza, M. W., 1992. Dietary sources of conjugated dienoic isomers of linoleic acid, a newly recognized class of anticarcinogens. J. Food Compos. Anal. 5, $185-197$. https://doi.org/10.1016/0889-1575(92)90037-K

Coşge, B. \& Gürbüz, M. K., 2007. Oil content and fatty acid composition of some safflower (Carthamus tinctorius L.) varieties sown in spring and winter. Eng. Sci. 1, 11-15.

De Smet, S. \& Vossen, E., 2016. Meat: The balance between nutrition and health. A review. Meat Sci. 120, $145-156$. https://doi.org/10.1016/j.meatsci.2016.04.008

Dilzer, A. \& Park, Y., 2012. Implication of conjugated linoleic acid (CLA) in human health. Crit. Rev. Food Sci. Nutr. 52 , 488-513 https://doi.org/10.1080/10408398.2010.501409.

Gecgel, U., Demirci, M., Esendal, E. \& Tasan, M., 2007. Fatty acid composition of the oil from developing seeds of different varieties of safflower (Carthamus tinctorius L.). J. Am. Oil Chem. Soc. 84, 47-54. https://doi.org/10.1007/s11746-006-1007-3

Hartman, L. \& Lago, R. C., 1973. Rapid preparation of fatty acid methyl esters from lipids. Lab. Pr. 22, 475-477.

Houben, J. H., Van Dijk, A., Eikelenboom, G. \& Hoving-Bolink, A.H., 2000. Effect of dietary vitamin E supplementation, fat level and packaging on colour stability and lipid oxidation in minced beef. Meat Sci. 55, $331-336$. https://doi.org/10.1016/S0309-1740(99)00161-8

Jardim, R. D., Carlos, J., Teresa, M., Osório, M., De Mendonça, ..., Prediée, G., 2007. Composição tecidual e química da paleta e da perna em ovinos da raça corriedale. pp 231-236.

Jenkins, B., West, J. A. \& Koulman, A., 2015. A review of odd-chain fatty acid metabolism and the role of pentadecanoic acid (C15:0) and heptadecanoic acid (C17:0) in health and disease. Molecules 20, 2425-2444. https://doi.org/10.3390/molecules20022425

Kostik, V., Memeti, S. \& Bauer, B., 2013. Fatty acid composition of edible oils and fats. J. Hyg. Eng. Des., $112-116$.

Kott, R. W., Hatfield, P. G., Bergman, J. W., Flynn, C. R., Van Wagoner, H. \& Boles, J. A., 2003. Feedlot performance, carcass composition, and muscle and fat CLA concentrations of lambs fed diets supplemented with safflower seeds. Small Rumin. Res. 49, 11-17. https://doi.org/10.1016/S0921-4488(03)00052-X

Kott, R. W., Surber, L. M. M., Grove, A. V, Hatfield, P. G., Boles, J. A., Flynn, C. R. \& Bergman, J. W., 2010. Feedlot performance, carcass characteristics, and muscle cla concentration of lambs fed diets supplemented with safflower seeds and vitamin E. Sheep Goat Res. J. 25, 16-22.

Loor, J. J., Ueda, K., Ferlay, A., Chilliard, Y. \& Doreau, M., 2004. Biohydrogenation, duodenal flow, and intestinal digestibility of trans fatty acids and conjugated linoleic acids in response to dietary forage: concentrate ratio and linseed oil in dairy cows. J. Dairy Sci. 87, 2472-2485. https://doi.org/10.3168/jds.S0022-0302(04)73372-X

Matthaus, B., Ozcan, M., \& Al Juhaimi, F. 2015. Fatty acid composition and $€$ tocopherol profiles of safflower (Carthamus tinctorius L.) seed oils. Nat. Prod. Res., 29(2), 193e196. doi: 10.1080/14786419.2014.971316

Mertens, D. R., 2002. Gravimetric determination of amylase-treated neutral detergent fibre in feeds with refluxing in beakers or crucibles: Collaborative study. J. AOAC Int. 85, 1217-1240.

Mir, P. S., Mcallister, T. A., Scott, S., Aalhus, J., Baron, V., ..., Mir, Z., 2004. Conjugated linoleic acid-enriched beef production. 79, 1207-1211.

Nettleton, J. A., Brouwer, I. A., Geleijnse, J. M. \& Hornstra, G., 2017. Saturated fat consumption and risk of coronary heart disease and ischemic stroke: A science Update. Ann. Nutr. Metab. 70, 26-33. https://doi.org/10.1159/000455681

Osório, J. C. S. \& Osório, M. T. M., 2003. Produção de carne ovina: Técnicas de avaliação "in vivo" e na carcaça. Universidade Federal de Pelotas, Brazil. 73 pg. (Portuguese)

Odongo, N. E., Or-Rashid, M. M., Kebreab, E., France, J. \& McBride, B. W., 2007. Effect of supplementing myristic acid in dairy cow rations on ruminal methanogenesis and fatty acid profile in milk. J. Dairy Sci. 90, 1851-1858. https://doi.org/10.3168/jds.2006-541

Palmquist, D. L. \& Conrad, H. R., 1978. High fat rations for dairy cows. effects on feed intake, milk and fat production, and plasma metabolites. J. Dairy Sci. 61, 890-901. https://doi.org/10.3168/jds.S0022-0302(78)83667-4

Ragni, M., Tufarelli, V., Pinto, F., Giannico, F., Laudadio, V., Vicenti, A. \& Colonna, M. A., 2015. Effect of dietary safflower cake (Carthamus tinctorius L.) on growth performances, carcass composition and meat quality traits in Garganica breed kids. Pak. J. Zool. 47, 193-199.

Sales, J.\& Koukolová, V. 2011.Dietary vitamin E and lipid and color stability of beef and pork: Modeling of relationships. J. Anim. Sci., 89 (9), 2836-2848. https://doi.org/10.2527/jas.2010-3335

Santos-Silva, J., Bessa, R.J.B. \& Santos-Silva, F., 2002. Effect of genotype, feeding system and slaughter weight on the quality of light lambs. II. Fatty acid composition of meat. Livest. Prod. Sci. 77, $187-194$. https://doi.org/10.1016/S0301-6226(02)00059-3

Sniffen, C. J. J. \& Russell, J. B., 1992. A net carbohydrate and protein system for evaluating cattle diets: 11. Carbohydrate and protein availability. J. Anim. Sci., 3562-3577.

Van Cleef, E. H. C. B., D’Áurea, A. P., Fávaro, V. R., Van Cleef, F. O. S., ..., Ezequiel, J. M. B., 2017. Effects of dietary 
inclusion of high concentrations of crude glycerin on meat quality and fatty acid profile of feedlot fed Nellore bulls. PLoS One 12, 1-17. https://doi.org/10.1371/journal.pone.0179830

Van Soest, P. J., Robertson, J. B. \& Lewis, B. A., 1991. Methods for dietary fibre, neutral detergent fibre, and nonstarch polysaccharides in relation to animal nutrition. J. Dairy Sci. 74, 3583-3597. https://doi.org/10.3168/jds.S00220302(91)78551-2

Ulbricht, T. L. V. \& Southgate, D. A. T., 1991. Coronary heart disease: Seven dietary factors. Lancet 338, $985-992$. https://doi.org/10.1016/0140-6736(91)91846-M

Wheeler, T. L., Shackelford, S. D. \& Koohmaraie, M., 1995. Shear force procedures for meat tenderness measurement.Agricultural Research. pp1-7. Roman L. Hruska USDA, MARC, Clay Center, Nebraska, USA. 